to work with a publicly funded international consortium along the lines of the international human genome project. "It is a big debate in Geneva," he says. But he admits that this may be difficult. Whereas the US National Institutes of Health is playing the largest role in the human genome effort, Europe is strong in proteomics and would probably demand a leading role in any international effort.

At the same time, the political fragmentation of Europe means that there is little realistic hope of Europe getting organized quickly, says Bairoch. $\mathrm{He}$ points, for example, to the fiasco when the European Union almost let its foremost bioinformatics structure, the European Bioinformatics Institute, fall into bank-

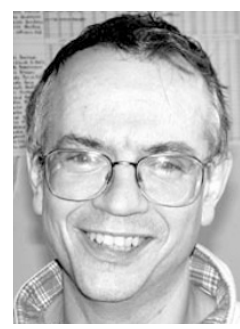

ruptcy (see Nature 402, 3-4; 1999). And when the publicly funded Swiss-Prot, one of the world's leading protein databases, faced closure for lack of money (see Nature 381, 266; Bairoch: fears loss 1996), it was only resof public access. cued by the creation of GeneBio, which ploughs 75 per cent of its profits back into the Swiss Institute of Bioinformatics.

A deal between Celera and Hochstrasser might prod the public sector into action, he adds. "I think the combination of having Celera in the human genome race was ultimately beneficial for all," says Robin Offord, a director of GeneBio.

Hochstrasser says, "We will try to make as much available for free as we can." But he argues that a compromise - such as an agreed delay in releasing data - may be needed to satisfy the demands of the private sector. "It is difficult to find the balance," he says. "We haven't signed yet because we would like free access to protein data. That is why it won't be GeneBio, but a new outfit."

Officials from the human genome project in the United States and Britain said comment would be premature since this was the first they had heard of a private-sector human proteome initiative.

Neither Celera nor Perkin-Elmer was available for comment. Heather Kowalski, corporate communications manager at Celera Genomics, explains that the companies are in a "quiet period" in the run-up to a secondary stock offering of 1.6 million Celera shares in early March.

The prospectus states that the offer is to fund "Celera's new product and technology development activities in functional genomics, with an emphasis on proteomics," as well as "general corporate purposes including possible acquisitions, alliances or collaborations". Declan Butler

\title{
Biomedical centre memorial to victims of Nazi research
}

Munich

The Max Delbrück Centre for Molecular Medicine (MDC) in Berlin, Germany's largest biomedical research centre, is to erect a memorial to the victims of the Nazis' 'euthanasia' programme, using DM1.5 million (US\$750,000) from the country's national lottery.

The MDC has planned a memorial for several years. It occupies the campus that once housed the Kaiser Wilhelm Institute (KWI) for Brain Research. Before the Second World War, the institute was one of the world's leading neuroscience research facilities - only recently has its involvement in Nazi experiments become public knowledge.

Detlev Ganten, the director of the MDC, says that the memorial, which depicts a handicapped child, will bear an inscription referring to this history and reminding readers of the ethics of clinical research. "A patient becomes a research object, and this difficult situation can very easily become abused," he explains.

The KWI's director during the Third Reich, Hugo Spatz, and his younger scientific collaborator, Julius Hallervorden, did research using brains from victims of the 'Aktion T4' - one part of the Nazi programme to exterminate lebensunwertes Leben (life not deemed worthy of living).

After the war, a US army officer interrogated Hallervorden. He admitted that when he learnt of the exterminations, he asked for brains to be removed and preserved so that "good use could be made of the material".
But he was never charged with any crime. Both Hallevorden and Spatz continued their careers and became respected members of Germany's scientific community. Hallervorden died in 1965, and his activities during the Nazi era only resurfaced in 1983, when his collection of brain sections - including material from children killed in the Aktion T4 - was rediscovered in the cellars of the Max Planck Institute for Brain Research in Frankfurt (see Nature 339, 498; 1989).

Correspondence between personnel at the Dachau concentration camp and SS leader Heinrich Himmler shows that Spatz both knew about and participated in the use of victims of the Nazis in research. It also reveals that he used brains from prisoners killed in Dachau in his research.

In the light of this information, there was a move three years ago to rename Hallervorden-Spatz disease — a rare childhood hereditary neurodegenerative disorder although this has not yet happened. But last year the name of the Hugo Spatz prize, awarded by the German Neurological Society, was discreetly changed to the Adolf Wallenberg prize, after the eminent JewishGerman neurologist who was forced to emigrate in 1938.

The plans for the memorial coincide with renewed efforts by Germany's science organizations to come to terms with their activities under the Nazis (see Nature 403, $474-475 ; 2000)$. A meeting on this theme will be held in May at the Bundesarchiv (federal archives) in Berlin.

Patrick Weydt

\section{Australian industry 'starving' R\&D}

\section{Sydney}

Australian scientists are as adept at commercializing their academic work as their US counterparts, according to a national survey - but industry continues to reduce its commitment to research and development.

The results were released two weeks ago, just before Australia's first National Innovation Summit. In 1998, the members of the Australian Tertiary Institutions Commercial Companies Association, which represents the business arms of 48 universities, evaluated the commercial potential of 274 inventions, filed 161 patent applications and were granted 103 patents.

Australian universities launched 46 successful start-up companies between 1996 and 1998. This equates to one company for every A \$100 million (US\$63 million) of university research funding - close to the average that a 1997 study found for US universities.

But Australia ranked 19 out of 24 leading economies in its business spending on research and development, as a percentage of gross domestic product (GDP), during 1996-97. The most recent estimate predicts that there was a further 10 per cent drop in such spending during 1998-99.

Contributing to government chief scientist Robin Batterham's review of the Australian science base, Vicki Sara, chair of the Australian Research Council, said that spending on university research has dropped by 13 per cent as a percentage of GDP over the four years of the coalition government. Peter Pockley 